\title{
Görsel Düşünme Stratejilerinin Uygulandığı Öğrenme Ortamlarında Fen Öğretmen Adaylarının Argümantasyon Düzeyleri
}

\section{Argumentation Levels of Pre-Service Science Teachers: With The Practices of Visual Thinking Strategies}

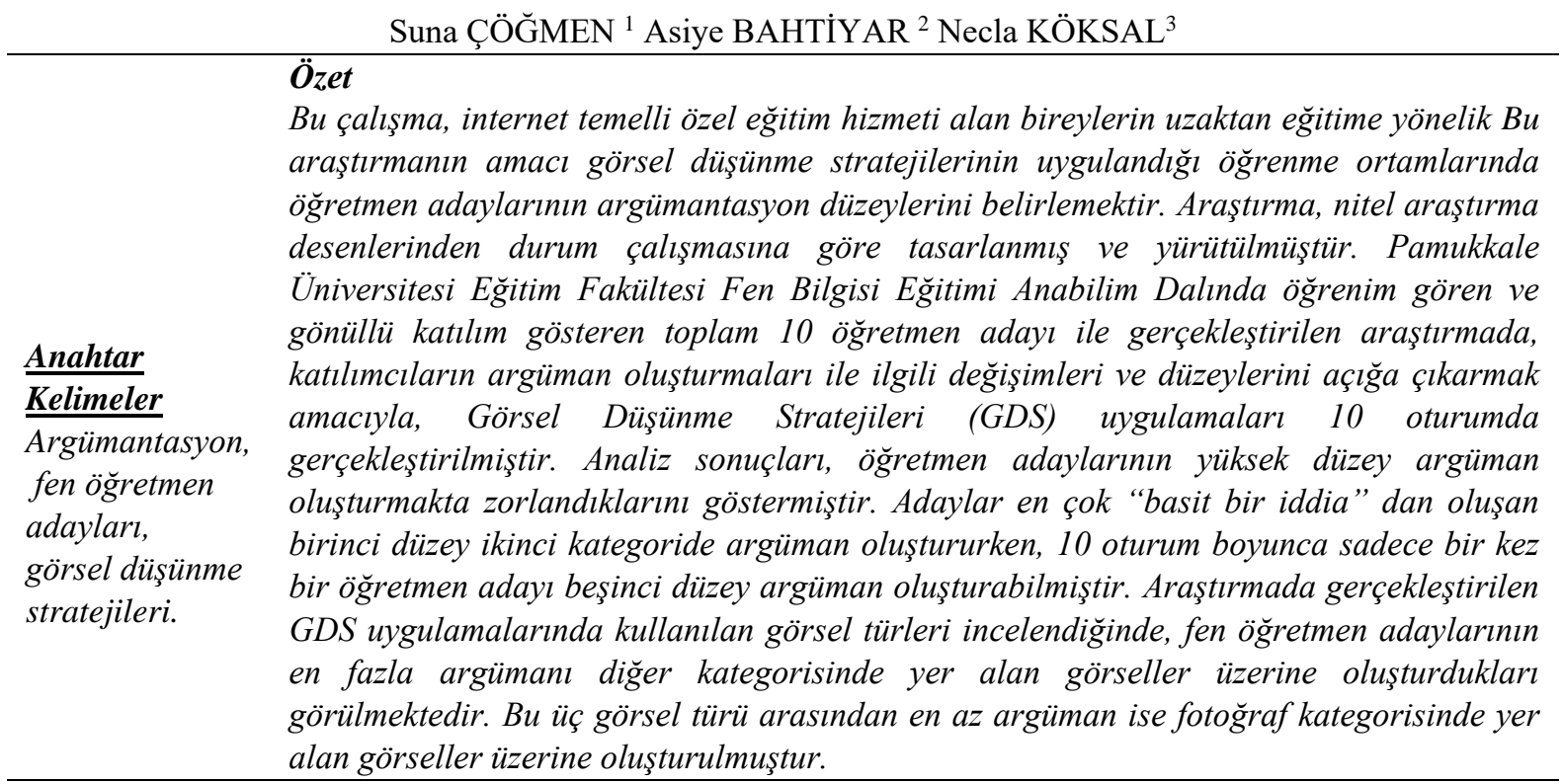

\section{Abstract}

The current study aims to determine the argumentation levels of pre-service science teachers in learning environments where Visual Thinking Strategies were applied. A Key Word holistic single case design was preferred for the study. Participants were 10 volunteer preArgumentation, service science teachers attending the Department of Science Education at Pamukkale preservice University. Ten sessions of Visual Thinking Strategies practices were implemented, and science the data was analyzed using descriptive analysis. Results show that pre-service science teachers, teachers construct low level arguments and have trouble with constructing high level and visual thinking qualified arguments. They constructed "a simple claim” the most. Examining the visuals strategies. $\quad$ used in VTS practices, images in the "other" category were the ones that the participants felt the most comfortable constructing arguments. Moreover, the least number of arguments among the categories took place in "photography".

\begin{tabular}{|c|c|}
\hline $\begin{array}{l}\text { Atıf için: } \\
\text { For Citation }\end{array}$ & $\begin{array}{l}\text { Çöğmen, S., Bahtiyar, A., \& Köksal, N. (2021). Görsel düşünme stratejilerinin uygulandığ } 1 \\
\text { öğrenme ortamlarında fen öğretmen adaylarının argümantasyon düzeyleri. Muğla Sitkl } \\
\text { Koçman Üniversitesi Eğitim Fakültesi [MSKU Journal of Education], 8(1), 289-306. DOI: } \\
\text { 10.21666/muefd.832920 }\end{array}$ \\
\hline & Received: 28.11 .2020 \\
\hline
\end{tabular}

\footnotetext{
${ }^{1}$ Pamukkale Üniversitesi, sunadem@pau.edu.tr, ORCID: 0000-0002-3969-5650

${ }^{2}$ Pamukkale Üniversitesi, abahtiyar@pau.edu.tr, ORCID: 0000-0002-4982-0785

${ }^{3}$ Pamukkale Üniversitesi,nkoksal@pau.edu.tr, ORCID: 0000-0003-2675-4305
} 
Ağır akademik eğitim ve sınav koşulları altında dünya üzerinde birçok çocuğun okul ortamından soğuduğu, ailelerin çocukları için farklı alternatiflere yönelmeye başladığı görülmektedir. $\mathrm{Bu}$ alternatiflerin; öğrencilerin ilgi ve ihtiyaçlarını merkeze alan, farklılıklara saygı duyan, çevresine duyarlı, öz düzenleme becerileri ve üst düzey düşünme becerileri gelişmiş bireyler olmalarına firsat veren öğrenme ortamları olmaları önemlidir. Bu çerçevede bireylerin düşünce yapılarını farklı bakış açıları ile zenginleştirerek, aynı zamanda fikirlerini oluştururken ve ifade ederken eleştirel bir pencereden bakarak geliştirmelerini sağlayan zengin eğitim ortamlarının düzenlenmesi gerekmektedir. Eğitim ortamları, öğrenenlerin yalnızca eğitim programlarında yer alan kazanımlara ulaşmasını sağlayan etkinlikleri içermez. Öğrenme öğretme süreci aynı zamanda öğrenenlere problem çözme, karar verme, çözüm üretme ve bir arada yaşama gibi becerileri de kazandıran etkinlikleri içermelidir. Öğrenenlerin 21. yy için sahip olması ve geliştirmesi gereken becerileri belirli başlıklar altında düzenleyerek sunan 21.yüzy1l Becerileri için İş Birliği [Partnership for 21st Century Skills (P21), 2019] kuruluşu, öğrenenlerin araştırma, öğrenme ve bilgiyi edinme becerilerini, yaratıcı ve eleştirel bir zeminde edinmesini vurgulamaktadır. Bir araştırma ve sorgulama temelli öğrenme yöntemi olarak da ele alınabilecek argümantasyon, 21. yy dünyasına uyum sağlamak ve bu dünyanın gerektirdiği niteliklere sahip olmak anlamında oldukça önemlidir.

Temellerini Toulmin'in 1958 yılında yazdığı "The Uses of Argument (Argüman Kullanımları)" eserinde attığı argümantasyon, bir öğretim yöntemi olarak eğitim ortamlarında sıklıkla kullanılmaktadır. Chen ve She (2012) argümantasyonu belirli bir iddiayı desteklemek ya da çürütmek için kanıt kullanmayı, iddialarla kanıtları bir argüman oluşturmak için birleştirmeyi, bilimsel bilgi iddiaları ve yargıları oluşturmayı ve güvenilir ve mutabakata varılmış bilimsel bilgiyi tanımlamayı içeren kolektif bilişsel gelişim süreci olarak tanımlamaktadır. $\mathrm{Bu}$ tanımdan yola çıkarak argümantasyon iddiada bulunma, bu iddiaları desteklemek için kanıtlar sıralama ve iddiaların geçerliliğini tartmak için kanıtları değerlendirmeyi içermektedir (Chin ve Osborne, 2010). Bir başka ifade ile argümantasyon basit bir iddialaşmadan öte, gerekçeler öne sürerek iddiaların ortaya konulması ve bu iddiaların desteklenmesidir. Toulmin (2003) modelinde bir argümanın en temel bileşenlerinin iddia, veri ve gerekçe olarak karşımıza çıktığını; daha karmaşık argümanların destekleyici, niteleyici ve çürütücü içerdiğini ifade etmektedir.

Crowell ve Kuhn (2014) argümantasyonun entelektüel bir beceri olarak da ele alındığını ifade etmişlerdir. Özellikle fen bilgisi derslerinde sıklıkla kullanılan argümantasyon uygulamasına yer verilen sınıflarda, öğrenciler iddialar üzerinden teoriler oluştururlar. Sonrasında veriler kullanarak kanıt sunarlar ve bir konu hakkındaki tahminlerini savunma veya çürütme yoluna giderler (Von Aufschnaiter, Erduran, Osborne ve Simon, 2008). Argümantasyon temelli öğretim yaklaşımında öğrencilerin hem kendi hem de arkadaşlarına ait var olan zihinsel modellerini sorguladıkları ve bunları birbiriyle karşılaştırdıkları görülmektedir. Öğrenciler bu süreçte doğru olduğunu düşündüğü modeli desteklemek için tıpkı bir bilim insanı gibi iddialar, gerekçeler ve kanıtlar kullanır (Aslan, 2010). Var olan modellerin desteklenmesi, geliştirilmesi ve değiştirilmesi sürecinde kavramsal bir değişim gerçekleşir ve öğrenciler bu sayede bilimsel bir süreç yürütmüş olurlar. Argümantasyon kullanımıyla ögrenciler iddia ve delil arasındaki bağlantıyı kurarak yeni düşünceler oluşturabilirler (Erduran, Simon ve Osborne, 2004).

Fen bilimleri, yalnızca dünyanın nasıl olduğuna ilişkin bilgi birikimini değil aynı zamanda dünyanın nasıl olabileceğine ilişkin açıklamalar sağlayan kuramların yapılandırılmasını da içerir (Erduran vd., 2004). Bu bilimsel bilgiler ve kuramlar, yeni buluşların ve araştırmaların da yönlendirmesiyle her zaman düzeltilmeye ve geliştirilmeye açık bir doğaya sahiptir. Bu durumda fen bilimlerinin de sürekli bir değişim içinde olduğu söylenebilir.

21.yüzyıl Becerileri için İş Birliği [Partnership for 21st Century Skills (P21), 2019] çalışmasında da belirtildiği üzere günümüz öğrenenleri, bu sürecin bir parçası olabilmek için yaratıcı düşünme, eleştirel düşünme, sorgulama ve yeni fikirler oluşturabilme gibi becerilere gereksinim duymaktadır. Ayrıca olanı hemen kabul etmeme ve şüphe duyma, kendine ait özgün fikirler üretebilme ve bu fikirleri gerekçelendirebilme gibi özelliklerine de sahip olmaları beklenmektedir. Son olarak 2018 yılında güncellenen Fen Bilimleri Dersi Öğretim Programının temel amaçları arasında da problem çözme, eleştirel düşünme ve iletişim becerilerinin yanı sıra bilgiyi üreten ve bilimsel süreç becerilerine hâkim bilim okur yazarı bireyler yetiştirmek yer almaktadır (MEB, 2018). Ceylan (2012), öğrencilere bilim ve bilimsel süreçlerin öğretilmesi ve kazandırılabilmesi için öncelikle bilimi temel amaçları doğrultusunda öğretebilecek eğitimcilere ihtiyaç duyulduğunu belirtmiştir. Bu ifade ile doğru orantılı 
olarak öğrenme sürecini; keşfetme, sorgulama, argüman oluşturma ve ürün tasarlama olarak tanımlayan programın (MEB, 2018) amaçlarına uygun bir şekilde uygulanması için fen bilimleri öğretmenlerinin de bu doğrultuda yetiştirilmesi gerekmektedir.

Dünyada ve Türkiye'de fen eğitiminde diğer alanlara göre daha sık kullanıldığı belirlenen argümantasyonun uygulandığı sınıflarda öğrencilerin akademik başarılarının arttığı, eleştirel düşünme, problem çözme, karar verme becerilerinin geliştiği ve argümantasyon sürecinin akran öğretiminden etkilendiği sonucu ortaya çıkmıştır (Chen ve She, 2012; Felton ve Kuhn, 2001; Gillies ve Khan, 2009; Nussbaum, 2011). Benzer şekilde Nussbaum (2002) argümantasyon yönteminin derslerde daha s1k kullanılmasının öğrencilerin üst düzey düşünme becerilerini geliştireceğini ifade etmiştir. Yine bir kısım araştırma bahsi geçen becerilerin, öğrenme ortamlarında argümantasyon temelli uygulamalara sıklıkla yer verilerek öğrencilere kazandırılabileceğini ortaya koymuştur (Güler, 2016; Hasançebi, 2014; Kaya ve Kılıç, 2008; Torun ve Şahin, 2016; Tümay ve Közeoğlu, 2011).

Jiménez-Aleixandre, Bugallo ve Duschl (2000), öğrencilerin genelde iddiada bulunurken argüman yapılandırmakta sorun yaşadıklarını ve onları bir veri ile destelemekte güçlük çektiklerini ifade etmişlerdir. Bu durumda öğrencilerin ayrıntılı ve üst bilişsel düşünme süreçlerinin desteklenmesi ihtiyacı ortaya çıkmaktadır. Bunun yanı sıra Torun ve Şahin (2016), argümantasyon sürecine uygun tasarlanmış sınıf ortamında öğrencilerin argüman düzeylerinin geliştirilmesinde kullanılan soru yapısının da önemli olduğunu ve öğrencilerin üst düzey düşünme becerilerini ortaya çıkaracak soruların kullanılması gerektiğini vurgulamışlardır.

Sanat yapıtları içinde barındırdığı belirsiz ve çok anlamlı özellikleri ile çok katmanlı düşünme süreçlerine rahatlıkla aracılık edebilirler (Köksal ve Çöğmen, 2019). Alma (2013) bir görsel üzerine düşünmenin özenli, keşfedici ve yaratıcı bir yol izlediğini ifade etmiştir. Sanat ile ilgili konuşma ve sanat yapıtını inceleme sürecinde bireyler sanat ile ilgili olmayan iletişim becerileri, problem çözme becerileri, eleştirel düşünme, yaratıcı düşünme ve analitik düşünme gibi becerileri de kazanabilmektedirler (Köksal ve Çöğmen, 2019). Tam da bu noktada Görsel Düşünme Stratejileri'nin (GDS) öğrencilere bu becerilerin kazandırılmasının yanı sıra sanat yapıtlarına daha fazla maruz kalarak bir estetik algı oluşturabilmelerini sağlayan etkili bir araç olabileceği düşünülmektedir (Housen, 2007).

Belirli kriterlere göre seçilmiş görsellerin, farklı yaş ve alt yapıdan gelen bireylerin oluşturduğu gruplarda, bir rehberin yönelttiği sorular çerçevesinde incelenmesini temel alan Görsel Düşünme Stratejileri eğitim ortamlarında eleştirel düşünme, problem çözme, yaratıcı düşünme, iletişim gibi çok sayıda becerinin geliştirilmesi amacıyla uygulanmaktadır (Bomgaars ve Bachelor, 2020; Cappello ve Walker, 2016; DeSantis ve Housen, 2012; Franco ve Unrath, 2014; Housen, 2001; Landorf, 2006; Moeller, Cutler, Fiedler ve Weier, 2013; Poiries, Newman ve Ronald, 2020; Yenawine ve Miller, 2014) Bilişsel psikolog Abigail Housen ve sanat eğitimcisi Philip Yenawine'in birlikte geliştirdiği bu stratejilerde herhangi bir sanat geçmişi olma koşulu taşımayan bir grup izleyen ile her biri üç farklı görsel içeren toplam 10 oturumluk bir süreç işletilmektedir. Oturumlarda görseller incelenirken izleyenlere "(1) Bu görselde neler oluyor?", “(2) Size bunu söyleten nedir?” ve "(3) Daha başka ne söyleyebilirsiniz?" olmak üzere üç temel soru eşlik etmekte, izleyenlerin görseli incelerken yaptıkları yorumları gerekçelendirmeleri ve derinlemesine düşünmeleri beklenmektedir (Housen, 2001). Aynı zamanda grup içerisinde bir etkileşim sağlanmakta ve farklı fikirlerin dinlenmesi, geliştirilmesi ve ortaya çıkması amacı da güdülmektedir. Örneğin "Bu görselde neler oluyor?" sorusunun ardından öğrencilerin gördüklerini gerekçelendirmelerinin istenmesi sadece gördüklerini değil gördükleri üzerine yaptıkları yorumlara da kanıt sağlamalarını gerektirmektedir.

Yukarıda bahsi geçen eleştirel düşünme, problem çözme, bilgi okuryazarlığı gibi becerilerin yanı sıra, görsel okuryazarlık da bir 21. yy becerisi olarak kabul edilmektedir (Bleed, 2005). Görsel okuryazarlık için de öğrenenlerin görsel eylemler, nesneler ve semboller aracıllğ̆ ile bilgiyi yorumlama, tanımlama, kabul etme ve anlama yeteneğine sahip olmaları gerektiği ifade edilmektedir (Finley, 2014). Görsel Düşünme Stratejileri, bir görsel üzerinden yapılandırılmış sorular aracılığıyla öğrencilerin yorum yapmalarına ve farklı yorumlar üzerinden iletişim kurmalarına aracı olmaktadır (Housen, 2001; Yenawine, 2019). Argümantasyon ise alternatif iddiaları değerlendirerek öğrencilerin yorumlama süreçlerini belirli bir kanıta dayandırmalarını temele almaktadır İyi bir argümanda savunulan iddia ile ilgili gerekçenin açıklanması ve yorumlanması gerekmektedir (Torun ve Fırat, 2020). Bu bağlamda GDS ve argümantasyon, farklı bakış açıları kazandırma ve bu bakış açılarının farkında olma ve 
tartışmaların belirli bir zemin üzerine yapılandırılması anlamında ortak bir zeminde buluşabileceği düşünülmektedir.

Görsel sanat; eleştirel düşünme, iletişim, aktif tartışma ve argümantasyonu geliştirebilir (Burnham ve Kai-Kee, 2005). Karmaşık altyapıları, bireysel üretim süreçleri, farklı bakış açılarına açık olmaları ve estetik özelliklerinden dolayı sanat yapıtları, bireylerin görsel düşünme ve aktif tartışma süreçlerini destekleyebilir. Bu yönüyle sanat yapıtları öğrencilerin görseli hem üretenin hem de iletişim halinde olduğu diğer bireylerin gözünden incelemelerini ve kendi fikirleri üzerine düşünmelerini sağlamaktadır. $\mathrm{Bu}$ bağlamda GDS, öğrencilerin düşünme süreçlerini yönlendirerek farklı değerlendirme açılarını hangi dayanaklara bağlı biçimde ürettiklerini sorgulamalarını da sağlar (Yenawine ve Miller, 2014). Chen ve She (2012), bakış açılarının ve anlamların birbirleriyle değişimi için öğrencilerin iletişim becerilerini geliştirmede büyük bir potansiyele sahip olan argümantasyonun görsel düşünme stratejileri ile ortaya çıkarılabileceğini belirtmektedir. Yukarıda da belirtildiği üzere sanat yapıtlarının kişilerin argüman oluşturmalarını desteklediği göz önünde bulundurulduğunda, eğitim ortamlarında görsellerden yararlanılarak kullanılan GDS'nin bireylerin argüman oluşturmalarına olumlu katkı sağlayacağı düşünülmektedir. Bu bağlamda araştırmanın amacı da görsel düşünme stratejilerinin uygulandığı öğrenme ortamlarında öğretmen adaylarının argümantasyon düzeylerini belirlemektir.

\section{Yöntem}

\section{Araştırma Modeli}

Görsel düşünme stratejilerinin uygulandığı öğrenme ortamlarında fen öğretmen adaylarının argümantasyon düzeylerini belirlemeyi amaçlayan bu araştırma, nitel araştırma desenlerinden durum çalışmasına göre tasarlanmış ve yürütülmüştür. Durum çalışması, bir araştırmanın nihai ürünü olarak tek bir varlığın, olgunun ya da sosyal birimin kapsamlı ve bütünsel betimlemesini ve analizini içerir (Merriam, 2009). Araştırmada, bir durum olarak ele alınan GDS uygulamalarında incelenen argümantasyon düzeyleri bütünsel olarak analiz edilmiş ve betimlenmiştir. GDS uygulamalarının tek bir durum olarak incelendiği araştırmada Yin'in (2003) sınıflamasına dayanılarak bütüncül tek durum deseni kullanılmıştır. Daha önce çalışılmayan veya ulaşılmayan durumlar, bütüncül tek durum deseni kullanılarak çalışılabilir. Böyle durumların çalışılması daha sonra yapılacak çalışmalara temel oluşturması ve yol göstermesi açısından önemlidir (Yıldırım ve Şimşek, 2013).

\section{Katılımcilar}

Araştırma, Pamukkale Üniversitesi Eğitim Fakültesi Fen Bilgisi Eğitimi Anabilim Dalında öğrenim gören ve gönüllü katılım gösteren toplam 10 öğretmen adayı ile gerçekleştirilmiştir. Altısı kadın ve dördü erkek olan öğretmen adaylarının tamamı üçüncü sınıf öğrencisidir. Katılımcıların belirlenmesinde kolay ulaşılabilir durum örneklemesine başvurulmuştur. Maliyet ve ulaşılabilirlik örneklem kararında dikkate alınmıştır. Bununla birlikte ölçüt örneklem yöntemi kullanılmış ve katılımcıların araştırmacıların tanımadığı veya derslerine girmediği öğretmen adayları olması ile sanat ile ilgili herhangi bir geçmiş deneyimleri bulunmaması ölçüt olarak alınmıştır. $\mathrm{Bu}$ ölçütler, katılımcıların düşüncelerini herhangi bir etki altında kalmadan ifade etmesi ve GDS uygulamalarının özellikle sanat geçmişleri olma şartı bulunmayan katılımcılara yönelik geliştirilmiş olması göz önünde bulundurularak belirlenmiştir.

\section{Araştırma Süreci}

Bir sanat eseri ile ilgili yapılan tartışmalarla bireylerin üst düzey düşünme becerileri, iletişim, grup çalışması gibi becerilerin geliştirilmesini amaçlayan GDS uygulamalarında her oturumda üç farklı sanat eseri incelenmektedir. Süreç boyunca katılımcılara yöneltilen üç soru ile tartışma ortamı yaratılmaktadır. "Bu görselde neler oluyor, size bunu dedirten ne görüyorsunuz ve daha fazla ne bulabilirsiniz?" soruları ile katılımcıların sanat eseri ile bağ kurmaları, düşüncelerini özgürce söylemeleri ve bu düşünceleri gerekçeleriyle açıklamaları istenmektedir. Böyle bir süreçte katılımcıların argüman oluşturmaları ile ilgili değişimleri ve düzeylerini açığa çıkarmak amacıyla yapılan bu çalışmada, Görsel Düşünme Stratejileri (GDS) uygulamaları 09.04.2018-09.05.2018 tarihleri arasında 10 oturumda gerçekleştirilmiştir. Uygulamalardan önce üç araştırmacı katılımcı grup ile bir araya gelmiş ve görsel düşünme, görsel düşünme stratejileri ve argümantasyon ile ilgili 
bilgilendirme ve tanışma toplantısı düzenlemiştir. Uygulamalar katılımcıların ders dışı zamanlarında gerçekleşeceği için ortak gün ve saatler belirlenerek uygulama takvimi oluşturulmuştur.

Araştırma U şeklinde oturma düzenine sahip toplantı salonunda yürütülmüştür. Katılımcılar birbirlerinin yüzlerini görecek şekilde oturmuşlar ve görsellerin yansıtıldığı ekran her katılımcının görebileceği şekilde konumlandırılmıştır. Görsellerin yansıtıldığ 1 esnada ortamdaki ışıklandırma, katılımcılardan gelen dönütlere göre (1şı açık/1şık kapalı) ayarlanmıştır. Oturumların kaydedildiği kamera, katılımcıların tamamını kadraja alacak ancak dikkatlerini dağıtmayacak şekilde salonun köşesine yerleştirilmiştir.

Her bir oturumda daha önceden belirlenen üç farklı sanat eseri sırayla incelenmiştir. İncelenen eserler; resim, fotoğraf ve diğer (minyatür, heykel vb.) görsellerden oluşmuştur. Görsel Anlayış Organizasyonu 1998 yılında GDS süreçlerinde kullanılacak görsel ürünlerin seçiminde dikkat edilmesi gereken özelliklerin yer aldığı bir rehber yayınlamıştır (Visual Understanding for Education, 2011). Buna göre görsel ürünlerin ulaşılabilir olması, açıklayıcı bir içeriğe sahip olması, hikâyelemeye olanak vermesi, ürün çeşitliliği açısından farklılık göstermesi, basitten karmaşığa doğru bir sıralama izlemesi, farklı yaş ve yerleşim bölgelerinden gelen izleyenlere hitap eden içeriklere sahip olması ve kendi aralarında belli bir ortak tema içermesi önemlidir. Araştırmada görseller yukarıdaki ölçütler dikkate alınarak seçilmiştir. Buna göre 10 resim, 9 fotoğraf ve 11 diğer kategoriden olmak üzere toplam 30 görsel seçilmiştir. Görsellerin künyelerine ilişkin açıklamalar her oturum için ayrı ayrı olarak bulgular kısmında sunulmuştur. Oturumlar farklı araştırmacılar tarafindan yönetilirken diğer araştırmacılar da süreçte katılımcı olarak yer almışlardır. Her bir oturum 32 ile 65 dakika arasında olmak üzere ortalama 50 dakika sürmüş ve sürecin tamamı katılımcıların izniyle video ile kaydedilmiştir.

\section{Verilerin Analizi}

Veriler nitel araştırma analiz yöntemlerinden betimsel analiz ile çözümlenmiştir. Öğretmen adaylarının argümanlarının düzeyini belirlemek için Erduran ve diğerleri (2004) tarafından geliştirilen Toulmin Argümantasyon Modelinden (TAM) yararlanılmıştır. TAM'ın Torun ve Şahin (2016) tarafindan Argümantasyon Değerlendirme Rubriği verilerin analizinde kullanılmıştır (Tablo 1).

Tablo 1

\begin{tabular}{|c|c|c|}
\hline DÜZEY & Puan & Argümantasyon İçeriği (Kriter) (KODLAR) \\
\hline \multirow{3}{*}{ Düzey 1} & 1 & Net bir iddia yok (dolaylı iddia) \\
\hline & 2 & Basit bir iddia \\
\hline & 3 & Basit bir iddia ve karşı iddia \\
\hline \multirow{3}{*}{ Düzey 2} & 1 & İddia+veri \\
\hline & 2 & İddia+veri+gerekçe \\
\hline & 3 & İddia+veri+gerekçe+destekleyici \\
\hline \multirow{3}{*}{ Düzey 3} & 1 & İddia+(veri)+çürütücü (Zayıf, net değil) \\
\hline & 2 & İddia+veri+gerekçe+çürütücü (Zayıf, net değil) \\
\hline & 3 & İddia+veri+gerekçe+destekleyici+çürütücü (Zayıf, net değil) \\
\hline \multirow{3}{*}{ Düzey 4} & 1 & İddia+veri+çürütücü (Net, açık, güçlü, bir tane) \\
\hline & 2 & İddia+veri+gerekçe+çürütücü (Net, açık, güçlü, bir tane) \\
\hline & 3 & İddia+veri+gerekçe+destekleyici+çürütücü (Net, açık, güçlü, bir tane) \\
\hline \multirow{3}{*}{ Düzey 5} & 1 & İddia+veri+çürütücü (Birden fazla, net) \\
\hline & 2 & İddia+veri+gerekçe+çürütücü (Birden fazla, net) \\
\hline & 3 & İddia+veri+gerekçe+destekleyici+çürütücü (Birden fazla, net) \\
\hline
\end{tabular}

Tablo 1'deki Rubrikte yer alan her bir düzeydeki argümantasyon içerikleri birer kategori olarak ele alınmış ve buna göre betimsel analiz yapılmıştır. Öncelikle veri seti Fen Eğitimi alanında uzman bir araştırmacı tarafından analiz edilmiştir. Daha sonra çalışmayı yürüten üç araştırmacı bir araya gelerek mevcut analizler üzerinden tekrar analiz yapmış ve çözümlemelere son hali verilmiştir.

Araştırmada geçerlik ve güvenirlik kaygılarını gidermek amacıyla birtakım stratejiler uygulanmıştır. Katılımcıları tanımak amacıyla on iki hafta gibi uzun süre etkileşimde bulunulmuştur. Stake'e (1995) 
göre, katılımcılar "durum çalışmasında rol almalarının yanı sıra yönlendirilmesinde de önemli bir rol' oynamalıdırlar (akt. Creswell, 2016). Bu bağlamda GDS uygulamalarında zaman zaman katılımcıların görüşleri doğrultusunda incelenen eserler tekrar gözden geçirilmiştir. Veriler araştırmacılar tarafindan iki aşamada analiz edilmiştir. Okuyucuların bilgileri farklı ortamlara aktarabilmelerini sağlamak amacıyla katılımcıların argümantasyon düzeylerine ilişkin zengin betimlemelere ve doğrudan alıntılara yer verilmiştir. Katılımcılar K1, K2 ...şeklinde kodlanmıştır.

\section{Bulgular}

Araştırma kapsamında görsel düşünme stratejilerinin uygulandığ kategoride olmak üzere toplam üç farklı görsel kullanılmıştır. Bulgular, oturumlarda sunulan görsellerin gösterilme sırasına göre tablolaştırılmıştır. Buna göre, birinci oturumda sunulan görsellere [Resim (Allan Rohan Crite, Tire Jumping in Front of My Window), Fotoğraf (Bruce Gilden, Magnum Photos Catalog), Diğer (Edvard Munch, Skrik)] ilişkin fen öğretmen adaylarının sahip oldukları argümantasyon düzeyleri ile ilgili bulgular aşağıdaki Tablo 2'de sunulmuştur.

Tablo 2

Birinci Oturumda Oluşturulan Argümantasyon Düzeyleri

\begin{tabular}{cccc|ccc|cccc|ccc|cc}
\hline \multirow{2}{*}{ Görseller } & \multicolumn{3}{c}{ Düzey 1 } & \multicolumn{3}{c|}{ Düzey 2 } & \multicolumn{3}{c|}{ Düzey 3 } & \multicolumn{3}{c|}{ Düzey 4 } & \multicolumn{3}{c}{ Düzey 5 } \\
\cline { 2 - 14 } & $\mathbf{1}$ & $\mathbf{2}$ & $\mathbf{3}$ & $\mathbf{1}$ & $\mathbf{2}$ & $\mathbf{3}$ & $\mathbf{1}$ & $\mathbf{2}$ & $\mathbf{3}$ & $\mathbf{1}$ & $\mathbf{2}$ & $\mathbf{3}$ & $\mathbf{1}$ & $\mathbf{2}$ & $\mathbf{3}$ \\
\hline Resim & 1 & 25 & 5 & 6 & 3 & 7 & 1 & 1 & - & - & - & - & - & - & - \\
Fotoğraf & - & 22 & 19 & 6 & 16 & 32 & 2 & 6 & - & 2 & - & 1 & - & 1 & - \\
Diğer & 1 & 18 & 6 & 8 & 16 & 12 & 3 & - & - & - & 3 & - & - & - & - \\
\hline Toplam & 2 & 65 & 30 & 20 & 35 & 51 & 6 & 7 & - & 2 & 3 & 1 & - & 1 & - \\
\hline
\end{tabular}

Tablo 2'ye göre, fen öğretmen adaylarının birinci oturumda en fazla (106) ikinci düzeyde, en az ise (1) beşinci düzeyde argüman oluşturdukları görülmektedir. Öğretmen adaylarının en fazla argümanı ise ikinci düzeyde ve fotoğraf görseline ilişkin oluşturdukları görülmektedir. Öğretmen adaylarının oluşturdukları argümanlara örnek alıntılar aşağıda sunulmuştur.

"Evet... O kadar adamın içinde mesela neden orada? Ya da mesela adamları neden dinlesin ki? Hani şüphe çeker zaten orada. Niye onların içine girsin?” (K1 / Fotoğraf, D5-2)

“Herkes kısa kollu giydiğine göre hava biraz sıcak bir gün.” (K2 / Fotoğraf, D2-2)

Bir resim (John Singer Sargent, The Daughters of Edward Darley Boit), bir fotoğraf (Alfred Eisenstaedt, Watching The Puppet Show), bir de diğer (Katsushika Hokusai, Women And Children Returning From An Inari Shrine Festival) kategoride olmak üzere toplam üç farklı görselin kullanıldığı ikinci oturumda, fen öğretmen adaylarının oluşturdukları argüman düzeylerine ilişkin bulgular aşağıdaki Tablo 3 'te sunulmuştur.

Tablo 3

İkinci Oturumda Oluşturulan Argümantasyon Düzeyleri

\begin{tabular}{|c|c|c|c|c|c|c|c|c|c|c|c|c|c|c|c|}
\hline \multirow{2}{*}{ Görseller } & \multicolumn{3}{|c|}{ Düzey 1} & \multicolumn{3}{|c|}{ Düzey 2} & \multicolumn{3}{|c|}{ Düzey 3} & \multicolumn{3}{|c|}{ Düzey 4} & \multicolumn{3}{|c|}{ Düzey 5} \\
\hline & 1 & 2 & 3 & 1 & 2 & 3 & 1 & 2 & 3 & 1 & 2 & 3 & 1 & 2 & 3 \\
\hline Resim & - & 21 & 1 & 3 & 8 & 5 & 3 & - & - & - & 1 & - & - & - & - \\
\hline Fotoğraf & - & 16 & 3 & 5 & 7 & 8 & 3 & 2 & - & - & - & - & - & - & - \\
\hline Diğger & - & 40 & 11 & 2 & 12 & 9 & 6 & 16 & 1 & - & 3 & 1 & - & - & - \\
\hline Toplam & - & 77 & 15 & 10 & 27 & 22 & 12 & 18 & 1 & - & 4 & 1 & - & - & \\
\hline
\end{tabular}

Tablo 3'e göre, öğretmen adaylarının ikinci oturumda en fazla (92) birinci düzeyde, en az ise (5) dördüncü düzeyde argüman oluştururken beşinci düzeyde hiç argüman oluşturamadıkları görülmektedir. Öğretmen adaylarının en fazla argümanı ise birinci düzeyde ve diğer kategorideki görsele ilişkin oluşturdukları görülmektedir. Öğretmen adaylarının oluşturdukları argümanlara örnek alıntılar aşağıda sunulmuştur.

“Kafasında çiçek gibi bir şey var.” (K3 / Diğer, D1-2)

“Hani sanki biraz daha uzakta o deniz. Bize sadece yakın geliyormuş gibi geldi bana." (K1 / Diğer, D12). 
"Bence bunlar pikniğe gelmiş, şu bence ă̆aca takılan kepenek falan olamaz. Kepenek ă̆ır bir şey yani kepeneğin ăgaç tepesinde olma gibi bir imkanı yok. Ben bu görüşe hiç katılmadım. Çocuğun bir oyuncă̆lydl ve çocuk uçurmuş, anneannesi ya da annesi çocuğu büyük bir ihtimalle sakinleştirmeye çalışıyorlar bir taraftan. Babası da onu ă̆açtan almaya çalışıyor gibi düşünüyorum ben." (K3 / Diğer, D4-3).

Bir diğer (Salvador Dali, La persistència de la memòria), bir resim (Georges Seurat, Un dimanche après-midi à l'île de la Grande Jatte), bir de fotoğraf (Lewis W. Hine, Newsboy on Street Corner) kategorisinde olmak üzere toplam üç farklı görselin kullanıldığ 1 üçüncü oturumda, fen öğretmen adaylarının oluşturdukları argüman düzeylerine ilişkin bulgular aşağıdaki Tablo 4'te sunulmuştur.

Tablo 4

Üçüncü Oturumda Oluşturulan Argümantasyon Düzeyleri

\begin{tabular}{|c|c|c|c|c|c|c|c|c|c|c|c|c|c|c|c|}
\hline \multirow{2}{*}{ Görseller } & \multicolumn{3}{|c|}{ Düzey 1} & \multicolumn{3}{|c|}{ Düzey 2} & \multicolumn{3}{|c|}{ Düzey 3} & \multicolumn{3}{|c|}{ Düzey 4} & \multicolumn{3}{|c|}{ Düzey 5} \\
\hline & 1 & 2 & 3 & 1 & 2 & 3 & 1 & 2 & 3 & 1 & 2 & 3 & 1 & 2 & 3 \\
\hline Diğer & - & 33 & 7 & 7 & 5 & 7 & 4 & - & - & - & - & - & - & - & - \\
\hline Resim & - & 40 & 8 & 3 & 9 & 20 & 7 & 5 & - & - & - & - & - & - & - \\
\hline Fotoğraf & - & 30 & 14 & 7 & 8 & 14 & 5 & 5 & - & 1 & 5 & - & - & - & - \\
\hline Toplam & - & 103 & 29 & 17 & 22 & 41 & 16 & 10 & - & 1 & 5 & - & - & - & - \\
\hline
\end{tabular}

Tablo 4'e göre, öğretmen adaylarının üçüncü oturumda en fazla (132) birinci düzeyde, en az ise (6) dördüncü düzeyde argüman oluştururken beşinci düzeyde hiç argüman oluşturamadıkları görülmektedir. Öğretmen adaylarının en fazla argümanı ise birinci düzeyde ve resim görseline ilişkin oluşturdukları görülmektedir. Öğretmen adaylarının oluşturdukları argümanlara örnek alıntılar aşağıda sunulmuştur.

“Herhalde şurada fil gibi bir şey yatıyor.” (K2 / Diğer, D1-2)

“Bence ele benziyor.” (K5 / Diğer, D1-2).

“Madem böyle kar yă̆dı birikecek kadar, niye kaldırımlar kuru?” (K4 / Fotoğraf, D4-1)

“Bunu bekliyordum ben de. Orada bir trafik ışığı varsa araba olması lazım, araba olursa da o karların kenarda birikmesi lazım. Yolun ortasında çünkü.” (K4 / Fotoğraf, D4-2)

Fen öğretmen adaylarının, bir resim (Pieter Bruegel, The Hunters In The Snow) ve iki diğer (Dominique Appia, Entre les trous de la memoire; The escape of Odysseus from the cave of Polyphemos, Geç Arkeic Dönem, MÖ 490-480) kategorideki görsel olmak üzere toplam üç farklı görselin kullanıldığı dördüncü oturumda oluşturdukları argüman düzeylerine ilişkin bulgular aşağıdaki Tablo 5'te sunulmuştur.

Tablo 5

Dördüncü Oturumda Oluşturulan Argümantasyon Düzeyleri

\begin{tabular}{|c|c|c|c|c|c|c|c|c|c|c|c|c|c|c|c|}
\hline \multirow{2}{*}{ Görseller } & \multicolumn{3}{|c|}{ Düzey 1} & \multicolumn{3}{|c|}{ Düzey 2} & \multicolumn{3}{|c|}{ Düzey 3} & \multicolumn{3}{|c|}{ Düzey 4} & \multicolumn{3}{|c|}{ Düzey 5} \\
\hline & 1 & 2 & 3 & 1 & 2 & 3 & 1 & 2 & 3 & 1 & 2 & 3 & 1 & 2 & 3 \\
\hline Resim & - & 29 & 6 & 5 & 7 & 7 & 7 & 1 & - & - & - & - & - & - & - \\
\hline Diğer & - & 26 & 1 & 1 & 5 & 14 & - & - & - & - & - & - & - & - & - \\
\hline Diğer & - & 18 & 3 & 2 & 4 & 5 & 2 & - & - & - & 2 & 1 & - & - & - \\
\hline Toplam & - & 73 & 10 & 8 & 16 & 26 & 9 & 1 & - & - & 2 & 1 & - & - & - \\
\hline
\end{tabular}

Tablo 5'e göre, öğretmen adaylarının dördüncü oturumda en fazla (83) birinci düzeyde, en az ise (3) dördüncü düzeyde argüman oluştururken beşinci düzeyde hiç argüman oluşturamadıkları görülmektedir. Öğretmen adaylarının en fazla argümanı ise birinci düzeyde ve resim görseline ilişkin oluşturdukları görülmektedir. Öğretmen adaylarının oluşturdukları argümanlara örnek alıntılar aşağıda sunulmuştur.

\footnotetext{
“Teknoloji gelişmemiş hiç bence burada.” (K3 / Resim, D1-2)

“Ya da mesela şey su donmuş onu kırmaya çalışlyorlar olabilir.” (K6 / Resim, D1-2)

“Bacakları falan da çok uzun bir koyuna göre.” (K1 / Diğer, D4-2)
} 
“Ama şöyle de bir şey var: eğer düşseydi atın bacă̆ının arasına nasıl gelebilirdi?” (K7 / Diğer, D4-2)

“Başı koyun, vücudu at gibi. Değişik bir yaratık olduğu için bence güçlü ve insan güçsüz kalmış. Hani kllıç ne kadar saplasa da şey yapsa da umursamıyor gibi, bilmiyorum.” (K7 / Diğer, D4-3)

Fen öğretmen adaylarının, bir resim (Benjamin West, William Penn's Treaty with the Indians in 1683), bir diğer (Marc Chagall, I and the Village) ve bir fotoğraf (Eve Arnold, American Actor Paul Newman at The Actors Studio) kategorisindeki görsel olmak üzere toplam üç farklı görselin kullanıldığı beşinci oturumda oluşturdukları argüman düzeylerine ilişkin bulgular aşağıdaki Tablo 6'da sunulmuştur.

Tablo 6

Beşinci Oturumda Oluşturulan Argümantasyon Düzeyleri

\begin{tabular}{|c|c|c|c|c|c|c|c|c|c|c|c|c|c|c|c|}
\hline \multirow{2}{*}{ Görseller } & \multicolumn{3}{|c|}{ Düzey 1} & \multicolumn{3}{|c|}{ Düzey 2} & \multicolumn{3}{|c|}{ Düzey 3} & \multicolumn{3}{|c|}{ Düzey 4} & \multicolumn{3}{|c|}{ Düzey 5} \\
\hline & 1 & 2 & 3 & 1 & 2 & 3 & 1 & 2 & 3 & 1 & 2 & 3 & 1 & 2 & 3 \\
\hline Resim & - & 24 & 7 & 4 & 9 & 5 & 2 & - & - & - & - & 2 & - & - & - \\
\hline Diğer & - & 30 & 9 & 3 & 7 & 7 & - & 1 & - & - & - & - & - & - & - \\
\hline Fotoğraf & - & 22 & 3 & 1 & 4 & 13 & 1 & 6 & 1 & - & - & - & - & - & - \\
\hline Toplam & - & 76 & 19 & 8 & 20 & 25 & 3 & 7 & 1 & - & - & 2 & - & - & - \\
\hline
\end{tabular}

Tablo 6'ya göre, öğretmen adaylarının beşinci oturumda en fazla (95) birinci düzeyde, en az ise (2) dördüncü düzeyde argüman oluştururken beşinci düzeyde hiç argüman oluşturamadıkları görülmektedir. Öğretmen adaylarının en fazla argümanı ise birinci düzeyde ve diğer kategorideki görsele ilişkin oluşturdukları görülmektedir. Öğretmen adaylarının oluşturdukları argümanlara örnek alıntılar aşağıda sunulmuştur.

\footnotetext{
"Bence bunların hepsi ayn sinıf insanlar. Şu klyafetli insanın eğilip oturup bir şey anlatmaya çalıştı̆ı̆na göre ortada bir sinif farkl yok. Tabi onlar üstün gibi gözükse de üstün falan değiller, eğilip de konuşana karşı. Şu karşıdaki beyazlyya karşı konuşuyor büyük bir ihtimalle. Oranın reisi o. Bence hani savaş gibi bir şey çıktl, kimin savaşa gidip gitmeyeceğine karar veriyormuş gibi geldi bana." (K3 / Resim, D4-3)

"Bence sinlf fark ver ve o adam onların hizmetçisi o yüzden eğiliyor. Mesela oradaki adam emrediyor ona "eğil, öyle kes"' falan bir şeyler diyor. O da oturuyor, kesiyor yani. Sinıf farkı var." (K7 / Resim, D4-3)

“Adamin üstünde kafasinda sanki bir ay var.” (K1 / Diğer, D1-2)

"Bence koyunun kafasına, koyunun tüm vücudunu ve kadını resmetmiş." (K5 / Diğer, D1-2)
}

Fen öğretmen adaylarının, bir resim (John Singleton Copley, Watson and the Shark), bir fotoğraf (Mohammed Salem/Reuters, Gaza Parkour) ve bir diğer (Pablo Picasso, Three Musicians) kategorideki görsel olmak üzere toplam üç farklı görselin kullanıldığı altıncı oturumda oluşturdukları argüman düzeylerine ilişkin bulgular aşağıdaki Tablo 7'de sunulmuştur.

Tablo 7

Altıncı Oturumda Oluşturulan Argümantasyon Düzeyleri

\begin{tabular}{|c|c|c|c|c|c|c|c|c|c|c|c|c|c|c|c|}
\hline \multirow{2}{*}{ Görseller } & \multicolumn{3}{|c|}{ Düzey 1} & \multicolumn{3}{|c|}{ Düzey 2} & \multicolumn{3}{|c|}{ Düzey 3} & \multicolumn{3}{|c|}{ Düzey 4} & \multicolumn{3}{|c|}{ Düzey 5} \\
\hline & 1 & 2 & 3 & 1 & 2 & 3 & 1 & 2 & 3 & 1 & 2 & 3 & 1 & 2 & 3 \\
\hline Resim & - & 28 & 6 & 4 & 6 & 8 & 4 & 3 & - & - & 4 & - & - & - & - \\
\hline Fotoğraf & 5 & 11 & 2 & 1 & 6 & 7 & 2 & 2 & 4 & 1 & 3 & - & - & - & - \\
\hline Diğer & 4 & 18 & 4 & 1 & 5 & 3 & - & - & - & - & - & - & - & - & - \\
\hline Toplam & 9 & 57 & 12 & 6 & 17 & 18 & 6 & 5 & 4 & 1 & 7 & - & - & - & - \\
\hline
\end{tabular}

Tablo 7'ye göre, öğretmen adaylarının altıncı oturumda en fazla (78) birinci düzeyde, en az ise (8) dördüncü düzeyde argüman oluştururken beşinci düzeyde hiç argüman oluşturamadıkları görülmektedir. Öğretmen adaylarının en fazla argümanı ise birinci düzeyde ve resim görseline ilişkin oluşturdukları görülmektedir. Öğretmen adaylarının oluşturdukları argümanlara örnek alıntılar aşağıda sunulmuştur.

"Ya da büyük gemiden hani oraya kaçamazlar, kıylya hafif sı̆̆ olur. O yüzden küçük teknelerle aktarllıyor olabilirler." (K3 / Resim, D4-2)

“Sı ğ sularda köpekbalıklarının ne işi var?” (K4 / Resim, D4-2) 
"Patlamış bitmiş orada dediler de orada kenarından duman çıkıyor, altında ateş yanıyor." (K8 / Fotoğraf, D4-2)

"Bunlar tanıdıkları da diğerleri farklı gruptan olabilir, 2 grup var.” (K2 / Resim, D1-2)

“Şu arkadaki gemilerden falan atılmıştır belki adam, onlar da görmüş kurtarlyorlardır.” (K9 / Resim, D1-2)

Fen öğretmen adaylarının, bir resim (Raffaello Sanzio, Scuola di Atene), bir fotoğraf (John Moore/Getty Images, U.S. Border Patrol) ve bir diğer (Scrulptre, Japonya, 19. yy) kategorideki görsel olmak üzere toplam üç farklı görselin kullanıldığı yedinci oturumda oluşturdukları argüman düzeylerine ilişkin bulgular aşağıdaki Tablo 8'de sunulmuştur.

Tablo 8

Yedinci Oturumda Oluşturulan Argümantasyon Düzeyleri

\begin{tabular}{|c|c|c|c|c|c|c|c|c|c|c|c|c|c|c|c|}
\hline \multirow{2}{*}{ Görseller } & \multicolumn{3}{|c|}{ Düzey 1} & \multicolumn{3}{|c|}{ Düzey 2} & \multicolumn{3}{|c|}{ Düzey 3} & \multicolumn{3}{|c|}{ Düzey 4} & \multicolumn{3}{|c|}{ Düzey 5} \\
\hline & 1 & 2 & 3 & 1 & 2 & 3 & 1 & 2 & 3 & 1 & 2 & 3 & 1 & 2 & 3 \\
\hline Resim & 1 & 21 & 6 & - & 10 & 2 & 1 & - & - & - & 1 & - & - & - & - \\
\hline Fotoğraf & - & 27 & 3 & - & 6 & 6 & 1 & 4 & 1 & - & 1 & - & - & - & - \\
\hline Diğer & 8 & 30 & 9 & 2 & 20 & 34 & 1 & 9 & - & - & 1 & - & - & - & - \\
\hline Toplam & 9 & 78 & 18 & 2 & 36 & 42 & 3 & 13 & 1 & - & 3 & - & - & - & - \\
\hline
\end{tabular}

Tablo 8'e göre, öğretmen adaylarının yedinci oturumda en fazla (105) birinci düzeyde, en az ise (3) dördüncü düzeyde argüman oluştururken beşinci düzeyde hiç argüman oluşturamadıkları görülmektedir. Öğretmen adaylarının en fazla argümanı ise birinci düzeyde ve diğer kategorideki görsele ilişkin oluşturdukları görülmektedir. Öğretmen adaylarının oluşturdukları argümanlara örnek alıntılar aşağıda sunulmuştur.

"Niye yaşlı erkekler topuz yapamıyor mu?” (K8 / Diğer, D4-2)

“Böyle soğuk bir yere benziyor.” (K1 / Fotoğraf, D1-2)

“Şuradaki adam etrafindakilere bilgi veriyormuş gibi duruyor.” (K2 / Resim, D1-2)

Fen öğretmen adaylarının, bir resim (Carl Spitzweg, The Poor Poet), bir fotoğraf (Leyla Emektar, The Collection of Children and Dreams) ve bir diğer (Stele of The Nubian soldier Nenu, Misır, MÖ 21002040) kategorideki görsel olmak üzere toplam üç farklı görselin kullanıldığı sekizinci oturumda oluşturdukları argüman düzeylerine ilişkin bulgular aşağıdaki Tablo 9'da sunulmuştur.

Tablo 9

Sekizinci Oturumda Oluşturulan Argümantasyon Düzeyleri

\begin{tabular}{|c|c|c|c|c|c|c|c|c|c|c|c|c|c|c|c|}
\hline \multirow{2}{*}{ Görseller } & \multicolumn{3}{|c|}{ Düzey 1} & \multicolumn{3}{|c|}{ Düzey 2} & \multicolumn{3}{|c|}{ Düzey 3} & \multicolumn{3}{|c|}{ Düzey 4} & \multicolumn{3}{|c|}{ Düzey 5} \\
\hline & 1 & 2 & 3 & 1 & 2 & 3 & 1 & 2 & 3 & 1 & 2 & 3 & 1 & 2 & 3 \\
\hline Resim & 4 & 28 & 3 & 4 & 22 & 19 & 5 & 4 & 1 & 1 & 2 & 2 & - & - & - \\
\hline Fotoğraf & 3 & 25 & 3 & - & 9 & 7 & 3 & 6 & 1 & - & - & - & - & - & - \\
\hline Diğer & 2 & 35 & 4 & 4 & 16 & 11 & 1 & 2 & - & - & - & - & - & - & - \\
\hline Toplam & 9 & 88 & 10 & 8 & 47 & 37 & 9 & 12 & 2 & 1 & 2 & 2 & - & - & - \\
\hline
\end{tabular}

Tablo 9'a göre, öğretmen adaylarının sekizinci oturumda en fazla (107) birinci düzeyde, en az ise (5) dördüncü düzeyde argüman oluştururken beşinci düzeyde hiç argüman oluşturamadıkları görülmektedir. Öğretmen adaylarının en fazla argümanı ise birinci düzeyde ve diğer kategorideki görsele ilişkin oluşturdukları görülmektedir. Öğretmen adaylarının oluşturdukları argümanlara örnek alıntılar aşağıda sunulmuştur.

\footnotetext{
"Bence soba değil. Çünkü oradaki şey boru olan kısım aşırı ince ve oradaki soba olsaydı dönemeç böyle dimdik olmazdl." (K6 / Resim, D4-3) “Bence yalnızlıktan canı sıkılmış bir adam hani şemsiye falan havaya atıyor bir şeyler yapmaya çalışıyor,
can sıkıntısını geçirmeye çalı̧̧ıyor.” (K3 / Resim, D2-2)
} 
"Aynen bence de özenmekle ilgili bir durum var ama sanki masadan çok o doğal ortama özenmişler gibi geldi bana. Hani artı böyle şeyler falan koymuşlar, buğdaylar. Isşte masa çiçekli, işte orada balonlar falan var. Hani doğal bir yerde, şehir hayatından yaşayan çocuklar olabilir. O şekilde hani daha çok doğal ortama özenmişler gibi masaya oturmaktansa” (K6 / Fotoğraf, D2-3).

“Belki de adamın bir günde yaşadı̆̆ı bir olay vardır.” (K7 / Diğer, D1-2)

Fen öğretmen adaylarının, bir resim (Norman Percevel Rockwell, Triple Self-portrait), bir diğer (Akhenaten, Nefertiti and Their Children) ve bir fotoğraf (Pavel Wolberg for The New York Times, An Israeli family took cover from incoming rockets near Ashdod) kategorisindeki görsel olmak üzere toplam üç farklı görselin kullanıldığg dokuzuncu oturumda oluşturdukları argüman düzeylerine ilişkin bulgular aşağıdaki Tablo 10'da sunulmuştur.

Tablo 10

Dokuzuncu Oturumda Oluşturulan Argümantasyon Düzeyleri

\begin{tabular}{|c|c|c|c|c|c|c|c|c|c|c|c|c|c|c|c|}
\hline \multirow{2}{*}{ Görseller } & \multicolumn{3}{|c|}{ Düzey 1} & \multicolumn{3}{|c|}{ Düzey 2} & \multicolumn{3}{|c|}{ Düzey 3} & \multicolumn{3}{|c|}{ Düzey 4} & \multicolumn{3}{|c|}{ Düzey 5} \\
\hline & 1 & 2 & 3 & 1 & 2 & 3 & 1 & 2 & 3 & 1 & 2 & 3 & 1 & 2 & 3 \\
\hline Resim & - & 28 & 4 & 2 & 18 & 10 & 2 & 6 & - & 1 & 1 & - & - & - & - \\
\hline Diğer & - & 20 & 5 & 5 & 5 & 4 & - & - & - & - & - & - & - & - & - \\
\hline Fotoğraf & - & 3 & 3 & 1 & 10 & 4 & 2 & 1 & - & 1 & 2 & - & - & - & - \\
\hline Toplam & - & 51 & 12 & 8 & 33 & 18 & 4 & 7 & - & 2 & 3 & - & - & - & - \\
\hline
\end{tabular}

Tablo 10'a göre, öğretmen adaylarının dokuzuncu oturumda en fazla (63) birinci düzeyde, en az ise (5) dördüncü düzeyde argüman oluştururken beşinci düzeyde hiç argüman oluşturamadıkları görülmektedir. Öğretmen adaylarının en fazla argümanı ise birinci düzeyde ve resim görseline ilişkin oluşturdukları görülmektedir. Öğretmen adaylarının oluşturdukları argümanlara örnek alıntılar aşağıda sunulmuştur.

"Fırçalar da yerde hep. Dă̆ınık çalışıyor yani." (K6 / Resim, D2-2)

"Emekli bir şeymiş sanki. Böyle bütün hayatını işine adar ögretmen olsun, başka bir meslek olsun. Ondan sonra emekli olunca bütün içinde kalanları yapar ya bu da böyle bir hobiymiş gibi içinde kalmış, yapamamış, şimdi yapmış gibi bir şey olabilir.” (K8 / Resim, D2-3)

“Omzunda okşuyor yüzünü.,” (K1 / Diğer, D1-2)

“Hayır, o okşamıyor. Kadının kulağına bir şeyler söylüyor bence.” (K3 / Diğer, D1-3)

“Korkulu bir şey olsa araba daha koruyucu, neden dişarı çıksınlar?” (K1 / Fotoğraf, D4-2)

Fen öğretmen adaylarının, bir resim (George Tooker, The Subway), bir diğer (Salvador Dali, Sunrise By The Ocean) ve bir fotoğraf (Bruno Catalano, Missing Pieces) kategorisindeki görsel olmak üzere toplam üç farklı görselin kullanıldığı onuncu oturumda oluşturdukları argüman düzeylerine ilişkin bulgular aşağıdaki Tablo 11'de sunulmuştur.

Tablo 11

Onuncu Oturumda Oluşturulan Argümantasyon Düzeyleri

\begin{tabular}{|c|c|c|c|c|c|c|c|c|c|c|c|c|c|c|c|}
\hline \multirow{2}{*}{ Görseller } & \multicolumn{3}{|c|}{ Düzey 1} & \multicolumn{3}{|c|}{ Düzey 2} & \multicolumn{3}{|c|}{ Düzey 3} & \multicolumn{3}{|c|}{ Düzey 4} & \multicolumn{3}{|c|}{ Düzey 5} \\
\hline & 1 & 2 & 3 & 1 & 2 & 3 & 1 & 2 & 3 & 1 & 2 & 3 & 1 & 2 & 3 \\
\hline Resim & - & 32 & 5 & 3 & 18 & 10 & 1 & 3 & - & - & - & - & - & - & - \\
\hline Diğer & 1 & 10 & 13 & 2 & 12 & 9 & 3 & - & - & - & - & - & - & - & - \\
\hline Fotoğraf & 4 & 17 & 4 & - & 7 & 6 & 3 & 5 & 1 & - & 1 & 1 & - & - & - \\
\hline Toplam & 5 & 59 & 22 & 5 & 37 & 25 & 7 & 8 & 1 & - & 1 & 1 & - & - & - \\
\hline
\end{tabular}

Tablo 11'e göre, öğretmen adaylarının onuncu oturumda en fazla (86) birinci düzeyde, en az ise (2) dördüncü düzeyde argüman oluştururken beşinci düzeyde hiç argüman oluşturamadıkları görülmektedir. Öğretmen adaylarının en fazla argümanı ise birinci düzeyde ve resim görseline ilişkin oluşturdukları görülmektedir. Öğretmen adaylarının oluşturdukları argümanlara örnek alıntılar aşağıda sunulmuştur.

“Şey sanki mahkeme salonu gibi geldi sanki.” (K7 / Resim, D1-2)

“Ama sanki o adamlar, o kadının kocası olamaz. Biraz yaşlı gibi...” (K6 / Resim, D3-2) 
“Oraya köprü değil de gemi yapacaklar gibi.” (K7 / Diğer, D1-3)

“Bence o insan düşmemiş, düşseydi ayakkabılarlyla beraber düşerdi. Yani ayakkabılarını ıslanmış olarak çıkarmış ve elbiseleriyle denize atlamış. Çantasını da bırakmış.” (K7 / Fotoğraf, D4-2)

Fen öğretmen adaylarının on haftalık oturum boyunca oluşturdukları argümanların düzeyleri ise aşağıdaki Tablo 12 'de verilmiştir.

Tablo 12

Oturumlarda Oluşturulan Argümantasyon Düzeyleri

\begin{tabular}{lccccc}
\hline & Düzey 1 & Düzey 2 & Düzey 3 & Düzey 4 & Düzey 5 \\
\hline 1. Oturum & 97 & 106 & 13 & 6 & 5 \\
2. Oturum & 92 & 59 & 31 & 6 & - \\
3. Oturum & 132 & 80 & 26 & 3 & - \\
4. Oturum & 83 & 50 & 10 & 2 & - \\
5. Oturum & 95 & 53 & 11 & 8 & - \\
6. Oturum & 78 & 41 & 15 & 3 & - \\
7. Oturum & 105 & 80 & 17 & 5 & - \\
8. Oturum & 107 & 92 & 23 & 5 & - \\
9. Oturum & 63 & 59 & 11 & 2 & - \\
10. Oturum & 86 & 67 & 16 & 45 & \\
\hline Toplam & 938 & 687 & 173 & & 1 \\
\hline
\end{tabular}

Tablo 12'ye göre, fen öğretmen adaylarının oluşturdukları argümanların düzeyleri oturumlara göre incelendiğinde, uygulama haftalarına göre doğrusal bir değişim göstermediği görülmektedir. Her bir oturumda farklı düzey ve sayıda argüman oluşturulması seçilen görsellerin türüne bağlı olarak değişkenlik göstermektedir. Bu görsellerin türlerine ilişkin oluşturulan argümanlara ait bulgular aşağıdaki Tablo 13'te sunulmuştur.

Tablo 13

Görsellere Göre Oluşturulan Argümanlar

\begin{tabular}{|c|c|c|c|c|c|c|c|c|c|c|c|c|c|c|c|c|}
\hline \multirow{2}{*}{ Görseller } & \multicolumn{3}{|c|}{ Düzey 1} & \multicolumn{3}{|c|}{ Düzey 2} & \multicolumn{3}{|c|}{ Düzey 3} & \multicolumn{3}{|c|}{ Düzey 4} & \multicolumn{3}{|c|}{ Düzey 5} & \multirow{2}{*}{ Toplam } \\
\hline & 1 & 2 & 3 & 1 & 2 & 3 & 1 & 2 & 3 & 1 & 2 & 3 & 1 & 2 & 3 & \\
\hline Resim & 6 & 276 & 51 & 34 & 110 & 93 & 33 & 23 & 1 & 2 & 9 & 4 & - & - & - & 642 \\
\hline Fotoğraf & 12 & 173 & 54 & 21 & 73 & 97 & 22 & 37 & 8 & 5 & 12 & 2 & - & 1 & - & 517 \\
\hline Diğer & 16 & 278 & 72 & 37 & 107 & 115 & 20 & 28 & 1 & - & 9 & 2 & - & - & - & 685 \\
\hline Toplam & 34 & 727 & 177 & 92 & 290 & 305 & 75 & 88 & 10 & 7 & 30 & 8 & - & 1 & - & 1844 \\
\hline
\end{tabular}

Tablo 13'e göre, fen öğretmen adaylarının oluşturdukları en fazla argüman (685) diğer kategorideki görsellere ilişkin olurken en az argümanı (517) ise fotoğraf görseline ilişkin oluşturdukları görülmektedir. Bununla birlikte oluşturulan argümanların en fazla (727) birinci düzeyin ikinci kategorisinde yer alan "basit bir iddia" olduğu, en az (1) ise beşinci düzeyin ikinci kategorisinde yer alan "iddia+veri+gerekçe+çürütücü (birden fazla, net)" olduğu görülmektedir.

\section{Sonuç, Tartışma ve Öneriler}

$\mathrm{Bu}$ araştırma, Görsel Düşünme Stratejileri'nin (GDS) uygulandığ 10 oturum boyunca fen öğretmen adaylarının oluşturdukları argümantasyon düzeylerini belirlemeyi amaçlamaktadır. Analiz sonuçları, öğretmen adaylarının yüksek düzey argüman oluşturmakta zorlandıklarını göstermiştir. Adaylar en çok "basit bir iddia" dan oluşan birinci düzey ikinci kategoride argüman oluştururken, 10 oturum boyunca sadece bir kez bir öğretmen adayı beşinci düzey argüman oluşturabilmiştir. Alan yazın incelendiğinde, katılımcıların argüman oluşturma konusunda etkili bir süreç işletemedikleri sonucu birçok araştırma tarafından da vurgulanmaktadır. Örneğin; Driver, Newton ve Osborne (2000), öğrencilerin bir an önce sonuca ulaşma eğilimi gösterdiklerini ve dolayısıyla da veri ve iddiayı görmezden geldiklerini belirtmişlerdir. Sadler (2004) öğrencilerin oluşturdukları argümanların kaliteli olmadığı sonucuna ulaşmış ve öğrencilerin argüman oluşturmada zorluk yaşadığını belirtmiştir. Khishfe $(2012,2014)$ de çalışmalarında, öğrencilerin sınırlı argümanlar geliştirdikleri, argümanlarına geçerli destekleyiciler sunamadıkları ve bilimin doğasına ilişkin orta düzeyde ve zayıf argümanlar geliştirdikleri sonucuna ulaşmıştır. Küçükaydın (2019) ise 8. sınıf öğrencileri ile yürüttüğü 
çalışmasında, öğrencilerin sadece bir tanesinin Toulmin'in dördüncü düzey argümanını oluşturduğunu, geri kalan öğrencilerin ise iddiaları verilerle desteklemekte güçlük yaşadığını bulmuştur. Bununla birlikte fen öğretmen adayları ya da fen bilimleri öğretmenleri ile yürütülen ve katılımcıların argümantasyon düzeylerini belirlemeye yönelik çalışmaların bulguları da benzerlik göstermektedir. Örneğin; Özcan, Aktamış ve Hiğde (2018) çalışmalarında yaptıkları gözlemlerde, fen bilimleri öğretmenlerinin etkili bir argümantasyon süreci başlatmak ve yürütmek konusunda zayıf kaldıkları sonucuna ulaşmışlardır. Özsevgeç ve Altun (2014), argümantasyon eğitimi almamış öğretmen adaylarıyla yürüttükleri çalışmada adayların zengin bir tartışma ortamı yaratmada yetersiz kaldıkları sonucuna ulaşmışlardır. Benzer bir şekilde Aydemir, Karakaya-Cırıt, Kaya ve Azger (2018) de çalışmalarında fen öğretmen adaylarının argüman oluşturma seviyelerinin düşük olduğunu belirtmişlerdir. Oysa öğrenme ortamlarının argümantasyon temelli düzenlendiği ve öğrencilerin argüman oluşturma konusunda gelişimlerinin gözlendiği araştırmalarda, uygulamalar ya da derslerin sonucunda öğrencilerin oluşturdukları argüman düzeyi ve kalitesinde artış olduğu sonuçlarına ulaşıldığı görülmektedir (Erduran vd, 2004; Kapucu ve Türk, 2019; Nussbaum ve Edwards, 2011; Torun ve Şahin, 2016; Zohar ve Nemet, 2002).

Fen bilimleri dersi, bilimin doğası gereği tartışma ve sorgulama temelli etkinliklerin rahatlıkla ve sıklıkla kullanılabildiği bir derstir. Toulmin (2003), argümantasyonu günlük yaşamın bir parçası olarak görürken bilimde akıl yürütmenin de ayrılmaz bir parçası olduğunu ifade etmektedir. Yapılan birçok araştırma da argümantasyon temelli gerçekleştirilen öğrenme ortamlarında öğrencilerin akademik başarılarının arttığını; eleştirel düşünme, problem çözme ve karar verme becerilerini geliştirdiği yönünde bulgulara sahiptir (Aslan, 2012; Aydın ve Kaptan, 2014; Demirel, 2015; Yıldız ve Ünal, 2016). Derslerin bu etkinlikler çerçevesinde işlenmesi, öğrencilerde bahsi geçen becerilerin geliştirilmesi konusunda firsatlar yaratmaktadır. Bu anlamda fen öğretmen adaylarının lisans öğrenimleri boyunca argümantasyon temelli öğrenme ortamlarıla daha sık ve etkili bir şekilde karşılaşmaları, argüman oluşturma süreçlerine yansıması açısından önemli görülmektedir. Benzer bir şekilde araştırmalar GDS uygulamalarının yer aldığı öğrenme ortamlarında da eleştirel düşünme ve iletişim becerilerinin geliştiği yönünde bulgulara ulaşmışlardır (Cappello ve Walker, 2016; DeSantis ve Housen, 2012; Franco ve Unrath, 2014; Housen, 2001; Landorf, 2006; Moeller, Cutler, Fieldler ve Weier, 2013; Yenawine ve Miller, 2014). GDS ve argümantasyon arasındaki bu ortak ilişki her ikisinin aynı ortamlarda kullanılarak yukarıda bahsi geçen birçok becerinin geliştirilmesine aracılık edebilir.

Eldeki çalışma sonuçları, fen öğretmen adaylarının sanat yapıtları üzerine tartışırken kaliteli argüman oluşturma konusunda sıkıntı yaşadıklarını göstermektedir. Burnham ve Kai-Kee (2005) görsel sanatın argümantasyon oluşturma konusunda etkili bir araç olabileceğini belirtmişlerdir. Chen ve She (2012) de GDS ve argümantasyon arasındaki ilişkiyi vurgulayarak bu stratejilerin kaliteli argüman oluşturma konusunda yardımcı olabileceğini ileri sürmüşlerdir. Bu noktada eldeki bulgu açısından, üzerine tartışılan konunun ve bağlamın ne olduğu ve kendi deneyimleriyle ne kadar ilişkilendirebildikleri, argüman oluşturma sürecinde önemli bir etken olarak karşımıza çıkmaktadır. Khishfe, Alshaya, BouJaoude, Mansour ve Alrudiyan (2017) bu durumu, bireylerin konuya aşinalıkları, konuyla ilgili ön bilgileri ve ilgisi gibi bağlamsal faktörlerin argüman üzerinde etkili olmasıyla ilişkilendirmişlerdir. Dolayısıyla fen öğretmen adaylarının sanat yapıtlarına ilişkin önceki deneyimleri, argüman oluşturma konusunda sıkıntı yaşamalarına neden olmuş olabilir. Bu bağlamda bireyin sanat yapıtlarıyla olan ilişkisine değinmekte fayda görülmektedir. Housen (2001) sanat yapıtı izleyenlerinin genellikle basit, somut ve kendilerine has gözlemler yaptıklarını ve insanları ve nesneleri kendilerine özgü bir anlatıda bir araya getirme eğilimi gösterdiklerini ifade etmektedir. Müze eğitimcisi olan Philip Yenawine ile geliştirdikleri GDS uygulamalarında, görsellere getirdikleri yorumlara ilişkin kategorilere ayrılan ve Başlangıç Düzey İzleyenleri olarak adlandırdıkları bu bireyler, bir sanat yapıtına ilişkin gözlemlerini, kendi yaşam çemberlerinden diğer bakış açılarına doğru (içten dişa doğru) bir şekilde yapmaktadırlar. $\mathrm{Bu}$ bağlamda da bir sanat yapıtına ilişkin yorumları görseldeki nesne, kişi ve olayların sıralanması ya da bu sıraladıklarına ilişkin özellikle kendi yaşamları ve deneyimlerinden yola çıkan kurgulardan oluşmaktadır. Fen öğretmen adaylarının oluşturdukları argüman düzeylerinin düşük olması, öne sürdükleri iddiaları bilimsel bir çerçeveye oturtamamaları ve karmaşık bir argüman yapısı içerisinde (veri, gerekçe, destekleyici, çürütücü) ifade edememeleri, yaşamlarında sanat yapıtları ile siklıkla karşılaşmamalarından kaynaklanıyor olabilir. 
Araştırmada gerçekleştirilen GDS uygulamalarında kullanılan görsel türleri incelendiğinde, fen öğretmen adaylarının en fazla argümanı diğer kategorisinde yer alan görseller üzerine oluşturdukları görülmektedir. Adaylar resim kategorisinde yer alan görselleri incelerken de buna yakın bir oranda argüman oluşturmuşlardır. Bu üç görsel türü arasından en az argüman ise fotoğraf kategorisinde yer alan görseller üzerine oluşturulmuştur. Berger (2012) fotoğrafın çoğu zaman sanıldığı gibi mekanik bir kayıt olarak görülmemesi gerektiğini, fotoğrafçının sınırsız görünüm arasından o görünümü seçtiğini belirtmiştir. Her ne kadar tercih edilmiş bir görme biçimi ve estetik değeri olsa da fotoğraf belli bir anın alıntılanmasından oluşan bir görsel türü olarak karşımıza çıkmaktadır. Sonntag (2005) bu konuda fotoğrafın; dünyanın parçaları, fotoğrafa aktarılmış görüntüler hatta herkesin yapabileceği ya da edinebileceği gerçeklik minyatürleri olduğunu ifade eder. Bu anlamıla bir belgeleme niteliği taşıyan fotoğraf, sanatsal içeriğinin yanı sıra hepimizin gündelik hayatta karşılaşabileceği türden bir gerçeklik kesiti içerir. Bu içeriğin gerçek hayata yakın olması da öğretmen adaylarının daha sınırlı argümanlar oluşturmalarına neden olmuş olabilir. Ancak ilginç bir şekilde, görsel türlerine göre düzeyler incelendiğinde, öğretmen adaylarının fotoğraf kategorisinde yer alan görseller söz konusu olduğunda daha üst düzey argümanlar oluşturduğu görülmektedir. Bir başka ifadeyle adaylar GDS oturumlarında genel olarak fotoğraflara ilişkin daha az sayıda argüman üretebilirken, bu argümanlara ilişkin veri, gerekçe, destekleyici, niteleyici ya da çürütücüleri de daha sıklıkla belirtmişlerdir. Bu durum fotoğraf görselinin fen öğretmen adaylarında daha tanıdık ve günlük yaşantı ile ilişki açısından daha gerçekçi bir imaj oluşturduğu, dolayısıyla da öne sürdükleri iddiaları diğer argüman öğeleriyle de destekleyerek daha güçlü ve ileri düzey argümanlar oluşturabildikleri ile açıklanabilir.

Diğer kategorisinde yer alan görseller arasında bulunan üç boyutlu heykel görselleri ve minyatür resimler adayların sayısız iddia oluşturabilecekleri veri kaynaklarıdır. Benzer bir biçimde resim kategorisinde yer alan, özellikle soyut resimler de adaylar için zengin iddia kaynakları oluşturmaktadır. Ancak bu görsellerde argüman oluşturma sıklıkları fazla olmasına rağmen düzeylerin düşük olması kayda değer bir bulgu olarak göze çarpmaktadır. Herhangi bir sanat geçmişi bulunmayan öğretmen adaylarının bir sanat yapıtı üzerine konuşurken görsellerin "gerçek" hikayelerini merak ettikleri, "doğru" yorumu bulma çabası içinde oldukları, bundan dolayı da sanat yapıtı ile ilgili argüman oluştururken sadece belirli bir düzeyde kaldıkları gözlenmiş̧ir. Sanat yapıtına ilişkin "anlaşılmaz" etiketi adayların kendi argümanlarını oluşturma konusunda kendilerini güvensiz hissetmelerine neden olmuş olabilir. Ancak fotoğraf gibi gerçek yaşam kesiti içeriğine sahip bir görselde adaylar daha net verilere sahip olduklarını düşündüklerinden argümanlarının sıklıklarını azaltmış fakat düzeylerini yükseltmiş olabilirler. Örneğin Patronis, Potari ve Spiliotopoulou (1999) çalışmalarında öğrencilerin kendi yaşamlarında karşılaşabilecekleri bir sorun karşısında argüman oluşturmakta başarılı olduklarını ve argüman kalitelerinin de iyi olduğunu bulmuşlardır.

Argümantasyon temelli öğrenme, öğrencilerin 21. yy becerilerini kazanmalarını desteklemesinin yanı sıra derslerin etkili ve eğlenceli bir bağlamda işlenmesine de yardımcı olmaktadır. Araştırmalar incelendiğinde bilimin doğası, bilim felsefesi ve çevre eğitimi ile ilgili konuların yanı sıra sosyal konular, hikayeler ve medya içeriklerinin argüman kaynağını oluşturduğu görülmektedir (Akkan ve Akhan, 2020; Crowell ve Kuhn, 2014; Demiral ve Çepni, 2018; Erduran vd, 2004; Eroğlu ve Yıldırım, 2020; Küçükaydın, 2019; Nussbaum, 2002; Seçkin Kapucu ve Türk, 2019; Torun ve Şahin, 2016). Fen eğitimi söz konusu olduğunda ise argümantasyon temelli uygulamalarda bilime ilişkin konuların ön plana çıktığı gözlenmektedir (Aslan, 2016; Aydemir vd, 2018; Chin ve Osborne, 2010; Ecevit ve Kaptan, 2019; Jiménez-Aleixandre vd, 2000; Özcan vd, 2018; Tüysüz, Demirel ve Yıldırım, 2013; Ulu, 2018; Von Aufschnaiter vd, 2007;). Elbette ki tartışılan konunun içeriği ve bağlamının önemi argüman oluşturma sürecinde göz ardı edilmemelidir. Ancak eldeki araştırma sonuçlarından da anlaşılacağ 1 üzere, öğretmen adaylarının sanat gibi zengin içeriğe sahip ve belirsizlik içeren bir kaynak söz konusu olduğunda argümantasyon düzeylerinin düşük kaldığ 1 ve sadece gerçek yaşam görüntülerine ilişkin daha net argümanlar ortaya çıkarabildikleri görülmektedir. Bu durum da farklı bakış açılarının ve estetik algının eksik kaldığını göstermektedir. Oysa araştırma ve sorgulamaya dayalı bir şekilde oluşturulan Fen Bilimleri Öğretim Programı, bireylere yaratıcı ve eleştirel düşünme becerisi kazandırmayı da amaçlamaktadır (MEB 2018). Arnheim (2015) görsel algının incelenen görselin edilgin bir kaydı olmadığını, tam aksine zihnin etkin bir faaliyeti olduğunu ifade etmektedir. $\mathrm{Bu}$ araştırmada argüman kaynağı olarak kullanılan sanat yapıtları da öğretmen adaylarının çok yönlü bir şekilde tartışmalarına ve birbirleriyle iletişim halinde olmalarına olanak tanımak amacıyla seçilmiştir. 
Ulaşılan bu sonuçlara göre, alandan bağımsız farklı ve çeşitli metin, güncel haber, sosyal medya gibi argüman kaynakları kullanılarak özellikle de sanatın gücünden yararlanılarak gerçekleştirilecek argümantasyon temelli uygulamaların sağlanması; öğretmen adaylarının daha üst düzeyde argüman oluşturmaları için lisans öğrenimleri süresince argümantasyon temelli uygulamaların arttırılması önerilebilir. Ulaşılan bu sonuçların yanı sıra eldeki çalışmanın katılımcı olarak yalnızca fen öğretmen adayları ve çalışma süresi olarak 10 hafta devam etmesi gibi bazı sınırlıkları bulunmaktadır. Yapılacak sonraki çalışmalarda farklı branşlardaki öğretmen adaylarıyla daha uzun süreli uygulamalara yer verilebilir. Ayrıca GDS oturumlarındaki kayıtların yanı sıra katılımcılardan farklı veri elde edilebilecek görüşme, günlük gibi yöntemlerin kullanıldığı araştırmaların yapılması; katılımcıların süreç boyunca farklı becerilere ilişkin gelişimlerinin incelenmesi önerilebilir.

\section{Kaynakça}

Akkan, M., \& Akhan, N. E. (2020). Sosyal bilgiler öğretmen adaylarının güncel olayları argümantasyon tekniği ile değerlendirmeleri. Avrasya Uluslararası Araştırmalar Dergisi, $8(21), 118-139$.

Alma, H. (2013). Storytelling as a dance of words and images. The relevance of visual thinking for perspective taking in stories. http://www.inter-disciplinary.net/probing-theboundaries/wpcontent/ uploads/2013/04/almaspaper.pdf adresinden 12.12.2016 tarihinde alınmıştır.

Arnheim, R. (2015). Görsel düşünme. İstanbul: Metis.

Aslan, S. (2012). Argümantasyon dayalı laboratuar uygulamalart: bilimsel süreç becerilerine ve laboratuar dersine yönelik tutuma etkisi. Proceedings of the 1st Cyprus International Congress of Education Research (s. 356-369). Girne: KEAB.

Aslan, S. (2016). Argümantasyona dayalı laboratuar uygulamaları: bilimsel süreç becerilerine ve laboratuar dersine yönelik tutuma etkisi. Hacettepe Üniversitesi Eğitim Fakültesi Dergisi, 31(4), 762-777.

Aydemir, S., Karakaya Cırıt, D., Kaya, S., \& Azger, C. (2018). Fen bilgisi öğretmen adaylarının argümantasyon ilişkin görüşleri ve argüman kurma becerilerinin araştırılması. Anemon Muş Alparslan Üniversitesi Sosyal Bilimler Dergisi, 6(STEMES'18), 131-138.

Aydın, Ö., \& Kaptan, F. (2014). Fen-teknoloji öğretmen adaylarının eğitiminde argümantasyonun biliş üstü ve mantıksal düşünme becerilerine etkisi ve argümantasyon ilişkin görüşleri. Eğitim Bilimleri Araştırmaları Dergisi, 4(2), 163-188.

Berger, J. (2012). Görme biçimleri. İstanbul: Metis.

Bleed, R. (2005). Visual literacy in higher education. Educause Learning Initiative, 1(1), 1-11.

Bomgaars, J.\& Bachelor, J. W. (2020). Visual thinking strategies: exploring artwork to improve output in the L2 classroom. Online Submission, 5(1), 1-34.

Burnham, R., \& Kai-Kee, E. (2005). The art of teaching in museum. The Journal of Aesthetic Education, 39(1), 65-76.

Cappello, M., \& Walker, N. (2016). Visual thinking strategies: teachers' reflections on closely reading complex visual texts within the disciplines. The Reading Teacher, 70(3), 317-325.

Ceylan, K. E. (2012). İlköğretim 5. sınıf öğrencilerine dünya ve evren öğrenme alanının bilimsel tartışma (argümantasyon) odaklı yöntem ile öğretimi. (Yayımlanmamış yüksek lisans tezi). Gazi Üniversitesi Eğitim Bilimleri Enstitüsü. Ankara.

Chen, C-H., \& She, H-C. (2012). The impact of recurrent on-line synchronous scientific argumentation on students' argumentation and conceptual change. Journal of Educational Technology\&Society, 15(1), 197-210. 
Chin, C., \& Osborne, J. (2010). Students' questions and discursive interaction: Their impact on argumentation during collaborative group discussions in science. Journal of Research In Science Teaching, 47(7), 883-908.

Creswell, J. W. (2016). Nitel araştırma yöntemleri: Beş yaklaşıma göre nitel araştırma ve araştırma deseni. (M. Bütün ve S. B. Demir, Çev. Ed.). Ankara: Siyasal Kitabevi.

Crowell, A., \& Kuhn, D. (2014). Developing dialogic argumentation skills: A 3-year intervention study. Journal of Cognition and Development, 15(2), 363-381.

Demirel, R. (2015). Argümantasyon destekli öğretimin öğrencilerin kavramsal anlama ve tartışma istekliliklerine etkisi. Kastamonu Ĕgitim Dergisi, 24(3), 1087-1108.

Demiral, Ü., \& Çepni, S. (2018). Fen bilgisi öğretmen adaylarının sosyobilimsel bir konudaki argümantasyon becerilerinin incelenmesi. Ahi Evran Üniversitesi Kırşehir Eğitim Fakültesi Dergisi, 19(1), 734-760.

DeSantis, K., \& Housen, A. (2012). Aesthetic development and creative and critical thinking skills study. https://www.issuelab.org/resources/15725/15725.pdf adresinden 20.05.2017 tarihinde alınmıştır.

Driver, R., Newton, P., \& Osborne, J. (2000). Establishing the norms of scientific argumentation in classrooms. Science education, 84(3), 287-312.

Erduran, S., Simon, S., \& Orborne, J. (2004). TAPping into argumentation: developments in the application of toulmin's argument pattern for studying science discourse. Wiley InterSicence. Doi: $\quad 10.1002 /$ sce.20012. https://onlinelibrary.wiley.com/doi/abs/10.1002/sce.20012 adresinden 23.12.2019 tarihinde alınmıştır.

Eroğlu, E., \& Yıldırım, H. İ. (2020). Argümantasyon tabanlı öğrenme yaklaşımının ortaokul 6. sınıf öğrencilerinin çevreye yönelik tutum, davranış ve başarılarına etkisi. Gazi Ĕgitim Bilimleri Dergisi, 6(1), 42-68.

Felton, M., \& Kuhn, D. (2001). The development of argumentative discourse skill. Discourse Processes, $\quad 32(2), 135-153$.

Finley, T. (2014). Common core in action: 10 visual literacy strategies. https://www.edutopia.org/blog/ccia-10-visual-literacy-strategies-todd-finley 12.06.2016 tarihinde alınmıştır.

Franco, M., \& Unrath, K. (2014) Carpe diem: seizing the common core with visual thinking strategies in the visual arts classroom. Art Education, 67(1), 28-32.

Gillies, R.M., \& Khan, A. (2009). Promoting reaoned argumentation, problem solving and learning during small-group work. Cambridge Journal of Education, 39(1), 7-27.

Güler, Ç. (2016). Fen laboratuvarı derslerinde kullanılan "argümantasyon tabanlı bilim öğrenme" yaklaşımının, fen bilgisi öğretmen adaylarının akademik başarılarına etkisi ve yaklaşım hakkındaki görüşleri. (Yayımlanmamış yüksek lisans tezi). Akdeniz Üniversitesi Eğitim Bilimleri Enstitüsü. Antalya.

Hasançebi, F. (2014). Argümantasyon tabanlı bilim öğrenme yaklaşımının (ATBÖ) öğrencilerin fen başarıları, argüman oluşturma becerileri ve bireysel gelişimleri üzerine etkisi. (Yayımlanmamış doktora tezi). Atatürk Üniversitesi Eğitim Bilimleri Enstitüsü. Erzurum.

Housen, A. (2001). Eye of the beholder: Research, theory and practice. New York: Visual Understanding in Education. https://vtshome.org/wp-content/uploads/2016/08/5Eye-of-theBeholder.pdf adresinden 15.09.2018 tarihinde alınmıştır.

Housen, A. (2007). Art viewing and aesthetic development: Designing for the viewer. From periphery to center: Art museum education in the 21st century, 172, 179.

Jiménez-Aleixandre, M. P., Bugallo Rodríguez, A., \& Duschl, R. A. (2000). "Doing the lesson" or "doing science": Argument in high school genetics. Science Education, 84(6), 757-792. 
Kaya, O. N., \& Kılıı̧, Z. (2008). Etkin bir fen öğretimi için tartışmacı söylev. Ahi Evran Üniversitesi Kırşehir Eğitim Fakültesi Dergisi (KEFAD), 9(3), 89-100.

Khishfe, R. (2012). Relationship between nature of science understandings and argumentation skills: A role for counterargument and contextual factors. Journal of Research in Science Teaching, 49(4), 489-514.

Khishfe, R. (2014). Explicit nature of science and argumentation instruction in the context of socioscientific issues: An effect on student learning and transfer. International Journal of Science Education, 36(6), 974-1016.

Khishfe, R., Alshaya, F. S., BouJaoude, S., Mansour, N., \& Alrudiyan, K. I. (2017). Students' understandings of nature of science and their arguments in the context of four socio-scientific issues. International Journal of Science Education, 39(3), 299-334.

Köksal, N., \& Çöğmen, S. (2019). Altıncı sınıf öğrencilerinin görsel düşünme süreçleri. Eğitimde Nitel Araştırmalar Dergisi-ENAD, 7(2), 826-844. DOI: 10.14689/issn.2148-2624.1.7c.2s.15m

Küçükaydın, M.A. (2019). Sekizinci sınıf öğrencilerinin sosyobilimsel bir konuya ilişkin görüşleri ve argüman yapıları. Illköğretim Online (Elementary Education Online), 18(1), 174-189. DOI: 10.17051/ilkonline.2019.527195

Landorf, H. (2006). What's going on this picture? Visual thinking strategies and adult learning. New Horizons in Adult Education and Human Resource Development, 20(4), 28- 32.

MEB (2018). Fen bilimleri dersi öğretim programi. http://mufredat.meb.gov.tr/ProgramDetay.aspx?PID=325 adresinden 07.01.2020 tarihinde alınmıştır.

Merriam, S. B. (2009). Qualitative research: a guide to design and implementation (2nd ed.). San Francisco, CA: John Wiley \& Sons.

Moeller, M., Cutler, K., Fiedler, D., \&Weier, L. (2013). Visual thinking strategies, creative and critical thinking. Phi Delta Kappa, 95(3), 56-60.

Nussbaum, E.M. (2002). Scaffolding argumentation in the social studies classroom. The Social Studies, 93(2), 79-83.

Nussbaum, E.M. (2011). Argumentation, dialogue, theory, and probability modeling: alternative frameworks for argumentation research in education. Educational Psychologist, 46(2), 84-106.

Nussbaum, E. M., \& Edwards, O. V. (2011). Argumentation, critical questions, and integrative stratagems: Enhancing young adolescents' reasoning about current events. Journal of the Learning Sciences, 20(3), 433-488.

Özcan, R., Aktamış, H., \& Hiğde, E. (2018). Fen bilimleri derslerinde kullanılan argümantasyon düzeyinin belirlenmesi. Pamukkale Üniversitesi Eğitim Fakültesi Dergisi, 43, 93-106.

Özsevgeç, T., \& Altun, E. (2014). Fen bilgisi öğretmen adaylarının sözlü argüman oluşturma becerilerinin değerlendirilmesi. 11. Ulusal Fen Bilimleri ve Matematik Eğitimi Kongresi (UFBMEK). Adana 11-14 Eylül. Türkiye.

Patronis, T., Potari, D., \& Spiliotopoulou, V. (1999). Students' argumentation in decision-making on a socio-scientific issue: implications for teaching. International Journal of Science Education, 21(7), 745-754.

Poirier, T. I., Newman, K., \& Ronald, K. (2020). An exploratory study using visual thinking strategies to improve undergraduate students' observational skills. American Journal of Pharmaceutical Education, 84(4).

Sadler, T. D. (2004). Informal reasoning regarding socioscientific issues: A critical review of research. Journal of Research in Science Teaching, 41(5), 513- 536. 
Seçkin Kapucu, M., \& Türk, H. (2019). Güncel bilimsel haberlerin Toulmin argüman modeline göre incelenmesi ve öğrencilerin argüman düzeylerinin belirlenmesi. Egitimde Nitel Araşstırmalar Dergisi - Journal of Qualitative Research in Education, 7(3), 1119-1144. DOI:10.14689/issn.2148- 624.1.7c.3s.10m

Sonntag, S. (2011). Fotoğraf üzerine. İstanbul: Agora Kitaplı̆̆ı.

Torun, F., \& Şahin, S. (2016). Argümantasyon temelli sosyal bilgiler dersinde öğrencilerin argüman düzeylerinin belirlenmesi. Eğitim ve Bilim, 41(186), 233-251.

Torun, F., \& Fırat, E. A. (2020). Öğretmen adaylarının argümantasyon düzeylerinin ve argüman oluşturma sürecinde yaptıkları hataların belirlenmesi. Firat Üniversitesi Sosyal Bilimler Dergisi, 30(1), 119-135.

Toulmin, S.E. (2003). The uses of argument (Updated Edition). United Kingdom: Cambridge University Press.

Tümay, H., \& Köseoğlu, F. (2011). Kimya öğretmen adaylarının argümantasyon odaklı öğretim konusunda anlayışlarının geliştirilmesi, Türk Fen Eğitimi Dergisi, 8(3), 105-119.

Tüysüz, C., Demirel, O. E., \& Yıldırım , B. (2013). Investigating the effects of argumentation, problem

and laboratory based instruction approaches on pre-service teachers' achievement concerning the concept of acid and base. Procedia - Social and Behavioral Sciences, 93, 1376-1381.

Visual Understanding for Education (2011). Guidelines for image selection for beginning viewers. www.visualthinkingstrategies.org adresinden 14.03.2017 tarihinde alınmıştır.

Von Aufschnaiter, C., Erduran, S., Osborne, J., \& Simon, S. (2008). Arguing to learn and learning to argue: Case studies of how students' argumentation relates to their scientific knowledge. Journal of Research in Science Teaching: The Official Journal of the National Association for Research in Science Teaching, 45(1), 101-131.

Ulu, C. (2018). Fen bilimlerinde öğrencilerin oluşturdukları argümanların kalitesi ile kavram öğrenme seviyeleri arasındaki ilişki. Uluslararası Bilim ve Eğitim Dergisi, 1(1), 11-24.

Yenawine, P. (2019). Art in School: As Essential as Language. American Educator, 43(1), 22-27.

Yenawine, P., \& Miller, A. (2014). Visual thinking, images, and learning in college. About Campus: Enriching the Student Learning Experience, 19(4), 1-8. wileyonlinelibrary.com adresinden 12.11.2018 tarihinde alınmıştır.

Yin, R. K. (2003). Case Study Research Design and Methods (3. Baskl). London: Sage Publications.

Yıldırım, A., \& Şimşek, H. (2013). Sosyal bilimlerde nitel araştırma yöntemleri. (9. Baskı). Ankara: Seçkin Yayıncılık.

Yıldız, K., \& Ünal, Ş. (2016). Biyoloji dersi çevre konularının öğretiminde örnek olay inceleme ve argümantasyon yöntemlerinin etkisi. Informal Ortamlarda Araştırmalar Dergisi, 1-23.

Zohar, A., \& Nemet, F. (2002). Fostering students' knowledge and argumentation skills through dilemmas in human genetics. Journal of Research in Science Teaching, 39(1), 35-62.

21. yy Becerileri için İşbirliği (Partnership for 21st Century Skills-P21) http://static.battelleforkids.org/documents/p21/P21_Framework_Brief.pdf $\quad$ adresinden 03.01.2020 tarihinde alınmıştır.

\section{Extended Abstract}

The learners of today need skills like creative and critical thinking, questioning, and constructing new ideas to be a part of this process. Besides those mentioned skills like critical thinking or problemsolving, visual literacy is also counted as a 21 st-century skill. What Finley (2014) refers to visual literacy is that it is a commenting, identifying, accepting, and comprehending ability of information via visual actions, objects, and symbols. This definition also highlights how Visual Thinking 
Strategies (VTS) functions as a tool with which learners can comment on a visual and communicate through different comments. Furthermore, VTS guides the thinking process of the learners and makes them question their justifications. In the same way, argumentation is based on evidence that the learners give for their comments by evaluating alternative claims. Therefore, VTS and argumentation meet in a common base in terms of constructing discussions on various points of view and being aware of those views. In this sense, current study aims to examine the argumentation levels of preservice science teachers in the learning environments where VTS is implemented.

\section{Methodology}

A case-study approach was chosen for the current research. Participants of the research consist of 10 volunteer pre-service science teachers attending the Primary Science Education Department at Pamukkale University. Ten of the VTS practices were implemented between the dates of 9.04.2018 and 09.05.2018. Descriptive analysis was used for the data. To determine the argumentation levels of preservice teachers, Toulmin Argumentation Model (TAM) developed by Erduran, et al., (2004) was referred. Argumentation Evaluation Rubric developed by Torun and Şahin (2016) was used.

\section{Findings}

Results outlined that pre-service science teachers have trouble with constructing high-level arguments. Pre-service teachers mostly construct arguments in the second category of the first level which is "a simple claim". Only one pre-service teacher had the fifth level of argumentation once throughout the ten practices. Another finding of the current research is that pre-service science teachers have difficulty in constructing qualified arguments while discussing works of art. Moreover, they construct arguments on the "other" category of visuals the most. The picture category also had a similar amount of arguments by the pre-service science teachers. The least number of arguments belong to photography.

\section{Discussion}

Argumentation based learning helps learners get $21^{\text {st }}$-century skills and provide an effective and enjoyable learning environment. As for science education, argumentation-based activities are usually implemented via science-related subjects. Although the importance of content and context on argumentation should be regarded, pre-service teachers' argumentation level is low for a resource with rich and ambiguous content such as art. They just constructed more precise and concrete arguments for real-life sights. This finding shows the inefficiency of different and aesthetic perspectives. Arnheim (2015) states that visual perception is not a passive recording of a visual but an active action of the mind. Research on VTS concluded that VTS practices improve critical and communication skills. This common point might lead educators to use various sources of argumentation like art, one of which is VTS. In the current research, works of art were just chosen for sophisticated discussion and active interaction.

As for the findings of the current study some suggestions might be made both for future studies and the educators. For instance, independent from the field of the participants, apart from art text, social media or current news might be used as the argumentation resources. Moreover, argumentation-based activities might be increased throughout college life. Future studies might use various data collection tools such as observation and interview and might handle a different kind of skill development.

\footnotetext{
*Bu makaleye yazarlar eşit oranda katkı sağlamıştır.
} 